\title{
ORIGINAL ARTICLE \\ Receptor systems controlling natural killer cell function are genetically stratified in Europe
}

\author{
KJ Guinan ${ }^{1}$, RT Cunningham ${ }^{2}$, A Meenagh ${ }^{3}$, MM Dring ${ }^{1}$, D Middleton ${ }^{4}$ and CM Gardiner ${ }^{1}$ \\ ${ }^{1}$ School of Biochemistry and Immunology, Trinity College, Dublin, Ireland; 'Institute of Agri-Food E Land Use, School of \\ Biological Sciences, Queen's University, Belfast, Northern Ireland, UK; ${ }^{3}$ Northern Ireland Histocompatibility E Immunogenetics \\ Laboratory, Blood Transfusion Building, City Hospital, Belfast, Northern Ireland, UK and ${ }^{4}$ Royal Liverpool University Hospital \\ and Division of Immunology, School of Infection and Host Defence, Liverpool, UK
}

\begin{abstract}
Natural killer (NK) cells are components of the innate immune system that function in identifying and destroying aberrant or pathogen-infected cells. These functions are largely controlled by killer cell immunoglobulin-like receptors (KIRs). KIRs inhibit and activate NK cell functions through interactions with their ligands, epitopes encoded by human leukocyte antigen (HLA) class I genes (HLA-C1, C2 and BW4). Genes that encode KIR and their HLA ligands vary in frequency across human populations. Here, we characterize two Irish populations for KIR and HLA and determine the spatial distribution of functionally important KIR:HLA systems in Europe, a region known for its considerable underlying genetic stratification. We find that Southern Europe is a region characterized by higher frequencies of activatory KIR and strong inhibitory HLA ligand systems (2DL1:HLA-C2 and 3DL1:Bw4). A lower frequency of activatory KIR and the predominance of a comparatively weaker inhibitory ligand system (2DL3:HLA-C1) are observed northwards. Despite contrasting KIR:HLA systems in Northern and Southern Europe, there is a clear balance between inhibitory and activatory repertoires, and their ligands in both regions. These findings show 'functional stratification' of the epistatic KIR:HLA receptor system in Europe, the presence of which will likely affect NK cell-mediated immunity across different populations.
\end{abstract}

Genes and Immunity (2010) 11, 67-78; doi:10.1038/gene.2009.60; published online 20 August 2009

Keywords: NK cells; KIRs; HLA; Europe; genetic gradients; innate immunity

\section{Introduction}

Natural killer (NK) cells are key components of the innate immune system that function in identifying and destroying aberrant or pathogen-infected cells. ${ }^{1-3}$ These cells possess extensive diversity both in terms of cell surface receptor expression and function. A major component of this diversity stems from the expression of killer cell immunoglobulin-like receptors (KIRs), 16 of which are encoded on human chromosome 19.4,5 Under normal conditions, inhibitory KIR (2DL, 3DL) engage human leukocyte antigen (HLA) class I on the target cell surface and a signal is transduced to the NK cell that inhibits its cytotoxic activity. In the absence of HLA class I, for example, because of downregulation during viral infection, inhibitory KIR signals are not transduced to the NK cell and NK cells are more sensitive to activating signals derived from other cell surface receptors, for example, 'activatory' KIR (2DS, 3DS), which leads to NK cell activation and cytotoxicity against target cells. The balance in signaling derived from the functionally

Correspondence: Dr CM Gardiner, School of Biochemistry and Immunology, Trinity College, Dublin 2, Ireland.

E-mail: clair.gardiner@tcd.ie

Received 27 February 2009; revised 16 June 2009; accepted 9 July 2009; published online 20 August 2009 distinct activatory and inhibitory KIR is regarded as one of the key factors controlling NK cell cytotoxicity. ${ }^{3}$

Human leukocyte antigen class I molecules provides ligands for the KIR receptors. The HLA class I genes (HLA-A, HLA-B and HLA-C) are highly polymorphic. A dimorphism within the HLA-C locus in humans gives rise to two distinct classes of ligands, HLA-C1 and HLA$\mathrm{C} 2$, each with contrasting specificities for a number of KIR receptors on NK cells. ${ }^{6}$ The HLA-C1 allotype, characterized by having asparagine at position 80 , binds KIR 2DL2/3/2DS2.7,8 The HLA-C2 allotype, characterized by lysine at position 80 , is a ligand for $2 \mathrm{DL} 1 / \mathrm{S} 1 .{ }^{7,8}$ Polymorphism within the $H L A-B$ gene produces either Bw4 or Bw6 allotypes, the former of which are ligands for 3DL1 and possibly 3DS1. ${ }^{9}$ Given the inherent complexity of both KIR and their HLA class I ligands and the fact that they segregate independently on different chromosomes, these cell surface molecules need to be considered together for functional interactions to be appreciated. Indeed, functional studies have shown that NK cell responsiveness to infection varies greatly and that it depends on the compound KIR/HLA genotype of individuals. ${ }^{10,11} \mathrm{~A}$ relative hierarchy of inhibitory responses to HLA-C has been defined for KIR receptors with 2DL1, 2DL2 and 2DL3 providing progressively decreasing levels of inhibition to NK cells in response to HLA-C ligation. ${ }^{10,12,13}$ 3DL1-mediated NK cell inhibition through Bw4 is considered a strong 
inhibitory interaction. ${ }^{14}$ A number of activatory KIR (2DS1, 2DS2) also bind to HLA class I, albeit with weaker affinity and variation in the presence or absence of each can influence NK cell function. ${ }^{15,16}$

Several studies indicate that KIRs have evolved in humans to fulfill diverse functions as a consequence of a wide range of evolutionary pressures. The opposing functions of activatory and inhibitory KIR is believed to reflect underlying processes of balancing and positive selection in response to pressures imposed by pathogens and coevolution with their rapidly evolving HLA class I ligands. ${ }^{14,17-20}$ Evidence also suggests the emergence of KIR to fulfill important roles during pregnancy ${ }^{21-23}$ in which it has been shown that they influence the role of uterine NK cell in vascular remodeling during fetal trophoblast cell invasion of the deciduas. ${ }^{24}$ As a likely consequence of these selective pressures, KIR diversity at the genetic, phenotypic and functional levels is immense. For instance, polygenicity gives rise to a vast array of different KIR haplotypes in human populations. These haplotypes vary in terms of gene content and gene number and are categorized into two functionally distinct classes: ' $\mathrm{A}$ ' haplotypes have a restricted gene content and many lack any functional activatory KIR (contain genes 2DL1, 2DL3,3DL1,3DL2, 2DL4 and 2DS4), and ' $B$ ' haplotypes have more variable and increased gene content that includes activatory KIR. ${ }^{25,26}$ In addition, several KIR genes are highly polymorphic. ${ }^{14,27,28}$ This diversity results in variegated KIR expression in individuals, which influences the innate immune responses of NK cells. ${ }^{4,14,27,29}$

Significant progress has been made over the last 15 years in defining the nature and extent of KIR gene diversity across human populations. It is now well established that KIR genes vary in frequency between different population groups. ${ }^{30}$ The most extreme example of variation observed to date is the strikingly low frequency of activatory $K I R$ genes in southeast Asian populations compared with the Australian Aboriginals. ${ }^{31,32}$ Such differences are likely to be a consequence of a multitude of factors (founder effects, population bottlenecks, population admixture, contrasting demographic histories and natural selection), which have occurred since modern humans evolved. More recent studies have shown that certain neighboring populations of the same ethnic group exhibit dramatically different $K I R$ gene frequencies. ${ }^{20,33,34}$ Europe is a relatively small region geographically, but it is characterized by the presence of considerable underlying genetic stratification. The presence of multiple genetic gradients from genes and single nucleotide polymorphisms have been established in recent times, which broadly distinguish northern from southern Europeans. ${ }^{35-37}$ In this study, KIR gene and ligand frequencies were determined in two Irish populations and are compared with data reported for other European and Middle Eastern populations. Characterization of KIR and HLA diversity in the Irish population is of particular importance to this type of analysis, as genetic gradients increasing or decreasing into northwestern Europe often peak on this island. In addition, as an island on the western edge of Europe, Ireland has avoided many of the major historical population movements, which have shaped the extant European gene pool, and therefore represents a relatively homogeneous European population. As NK cell respon- siveness in individuals depends largely on both their KIR and HLA ligand genetic backgrounds, we investigated the spatial distribution of KIR receptors and their HLA ligands together in Europe. Given the extent of genetic structure in Europeans, we hypothesized that KIR genes and their ligands are likely to be stratified in Europe and this would reflect epistatic KIR and HLA functional units.

\section{Results}

KIR frequencies and genotypes are similar in two Irish populations

The potential for regional variations in KIR and HLA class I frequencies in Ireland was investigated by establishing and comparing the frequencies of KIR and their HLA class I ligands in two Irish populations, one from the Northern Ireland (Belfast, $n=183$ ) and the second from the Republic of Ireland (Dublin, $n=136$ ). $K I R$ gene frequencies were similar between the groups. KIR genotypes were also similar between the groups and the most common genotypes are represented to a similar degree in both groups (see Table 1). However, the most common AA genotype is more frequent in the northern cohort but this does not reach statistical significance ( 37.2 vs $31.6 \%, P>0.05)$. Both the Northern Ireland and Republic of Ireland samples display similar frequencies of HLA class I ligands (HLA-C1, HLA-C2, HLA-Bw4, see Supplementary Table S2).

Variation of KIR in worldwide populations reflects contrasting A/B haplotype backgrounds

In order to assess $K I R$ gene variability and to place the Irish populations that lie in a global context, principal component (PC) analysis was used to reduce total KIR variation in populations to just two dimensions. Frequencies of 10 commonly genotyped KIR (2DL1, 2DL2, 2DL3, 3DL1, 2DS1, 2DS2, 2DS3, 2DS4, 2DS5 and 3DS1) from 36 different populations were obtained from the literature and an online allele frequency database (see Materials and methods) and are combined with the Irish population data. Six population clusters are observed separately along two dimensions: South-East Asians, Southern Asians, Europeans/Middle Eastern, Africans, Native Americans and Australian Aborigines as a distinct divergent population (see Figure 1a). The first component (PC1) accounts for most of the variability observed between populations $(91.0 \%)$, with the second accounting for only $4.7 \%$ of the total variation. As expected, the Irish populations are observed to cluster closely together within the European/Middle Eastern group.

It is clear from PC analysis that the Australian Aboriginals are an extremely divergent population in this analysis. This is consistent with our knowledge of KIR genotype and haplotype diversity in human populations. It was well established before this study that Australian Aboriginals have one of the highest incidences of B haplotype-associated activatory KIR and the lowest A haplotype frequency in the world. ${ }^{31}$ Japanese on the other hand, have low B haplotype frequencies and the highest incidence of A haplotype KIR in the world. ${ }^{32}$ As these two populations flank the extreme ends of the first component (PC1), this 
Table 1 KIR Gene and genotype frequencies in Northern and Southern Irish cohorts

\begin{tabular}{|c|c|c|c|c|c|c|c|c|c|c|c|c|c|c|c|c|c|c|c|}
\hline \multicolumn{2}{|c|}{ Genotype } & \multirow[t]{2}{*}{ ले } & \multirow[t]{2}{*}{ กิ } & \multirow[t]{2}{*}{ ลิ } & \multirow[t]{2}{*}{ กิ } & \multirow[t]{2}{*}{$\overline{\widehat{\widehat{े}}}$} & \multirow[t]{2}{*}{ ลे } & \multirow[t]{2}{*}{ ले } & \multirow[t]{2}{*}{ 离 } & \multirow[t]{2}{*}{ ले } & \multirow[t]{2}{*}{ ले } & \multirow[t]{2}{*}{ 高 } & \multirow[t]{2}{*}{ 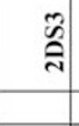 } & \multirow[t]{2}{*}{ 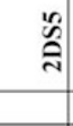 } & \multirow[t]{2}{*}{ సิ } & \multirow[t]{2}{*}{ సิ } & \multirow[t]{2}{*}{ लิ } & \multirow{2}{*}{$\begin{array}{c}\begin{array}{c}\text { North } \\
\% \text { (n) }\end{array} \\
37.16(68) \\
\end{array}$} & \multirow{2}{*}{$\begin{array}{c}\begin{array}{c}\text { South } \\
\%(n)\end{array} \\
31.62(43) \\
\end{array}$} \\
\hline 1 & AA & & & & & & & & & & & & & & & & & & \\
\hline 2 & $\mathrm{AB}$ & & & & & & & & & & & & & & & & & $14.21(26)$ & $16.91(23)$ \\
\hline 3 & $\mathrm{AB}$ & & & & & & & & & & & & & & & & & $12.02(22)$ & $13.24(18)$ \\
\hline 4 & $\mathrm{AB}$ & & & & & & & & & & & & & & & & & $7.65(14)$ & $5.88(8)$ \\
\hline 5 & $\mathrm{AB}$ & & & & & & & & & & & & & & & & & $5.46(10)$ & $4.41(6)$ \\
\hline 6 & $\mathrm{AB}$ & & & & & & & & & & & & & & & & & $3.83(7)$ & $4.41(6)$ \\
\hline 7 & $\mathrm{AB}$ & & & & & & & & & & & & & & & & & $3.28(6)$ & $2.21(3)$ \\
\hline 8 & BB & & & & & & & & & & & & & & & & & $2.73(5)$ & $3.68(5)$ \\
\hline 9 & BB & & & & & & & & & & & & & & & & & $2.73(5)$ & $0.74(1)$ \\
\hline 10 & BB & & & & & & & & & & & & & & & & & $1.64(3)$ & $2.21(3)$ \\
\hline 11 & BB & & & & & & & & & & & & & & & & & $1.64(3)$ & $0.74(1)$ \\
\hline 12 & $\mathrm{AB}$ & & & & & & & & & & & & & & & & & $1.09(2)$ & $0.74(1)$ \\
\hline 13 & $\mathrm{AB}$ & & & & & & & & & & & & & & & & & $1.09(2)$ & $0.74(1)$ \\
\hline 14 & BB & & & & & & & & & & & & & & & & & $0.55(1)$ & $2.21(3)$ \\
\hline 15 & BB & & & & & & & & & & & & & & & & & $0.55(1)$ & $1.47(2)$ \\
\hline 16 & $\mathrm{AB}$ & & & & & & & & & & & & & & & & & $0.55(1)$ & $0.74(1)$ \\
\hline 17 & BB & & & & & & & & & & & & & & & & & $0.55(1)$ & $0.74(1)$ \\
\hline 18 & BB & & & & & & & & & & & & & & & & & $0.55(1)$ & $0.74(1)$ \\
\hline 19 & AA & & & & & & & & & & & & & & & & & $0.0(0)$ & $1.47(2)$ \\
\hline 20 & $\mathrm{AB}$ & & & & & & & & & & & & & & & & & $0.0(0)$ & $0.74(1)$ \\
\hline 21 & $\mathrm{AB}$ & & & & & & & & & & & & & & & & & $0.0(0)$ & $0.74(1)$ \\
\hline 22 & $\mathrm{AB}$ & & & & & & & & & & & & & & & & & $0.0(0)$ & $0.74(1)$ \\
\hline 23 & BB & & & & & & & & & & & & & & & & & $0.0(0)$ & $0.74(1)$ \\
\hline 24 & BB & & & & & & & & & & & & & & & & & $0.0(0)$ & $0.74(1)$ \\
\hline 25 & BB & & & & & & & & & & & & & & & & & $0.0(0)$ & $0.74(1)$ \\
\hline 26 & BB & & & & & & & & & & & & & & & & & $0.55(1)$ & $0.0(0)$ \\
\hline 27 & BB & & & & & & & & & & & & & & & & & $0.55(1)$ & $0.0(0)$ \\
\hline 28 & BB & & & & & & & & & & & & & & & & & $0.55(1)$ & $0.0(0)$ \\
\hline 29 & BB & & & & & & & & & & & & & & & & & $0.55(1)$ & $0.0(0)$ \\
\hline 30 & BB & & & & & & & & & & & & & & & & & $0.55(1)$ & $0.0(0)$ \\
\hline 31 & $\mathrm{AB}$ & & & & & & & & & & & & & & & & & $0.0(0)$ & $0.74(1)$ \\
\hline \multirow{2}{*}{$\stackrel{\mathscr{E}}{\stackrel{E}{E}}$} & & $\begin{array}{c}100 \\
(183) \\
\end{array}$ & $\begin{array}{c}44.26 \\
(81)\end{array}$ & $\begin{array}{l}90.71 \\
(166) \\
\end{array}$ & $\begin{array}{c}44.26 \\
(81)\end{array}$ & $\begin{array}{l}97.27 \\
(178)\end{array}$ & $\begin{array}{l}97.27 \\
(178) \\
\end{array}$ & $\begin{array}{c}100 \\
(183)\end{array}$ & $\begin{array}{c}100 \\
(183)\end{array}$ & \begin{tabular}{|l|}
95.06 \\
$(175)$ \\
\end{tabular} & $\begin{array}{c}41.53 \\
(76) \\
\end{array}$ & $\begin{array}{c}49.18 \\
(90) \\
\end{array}$ & $\begin{array}{c}22.40 \\
(41)\end{array}$ & $\begin{array}{c}37.16 \\
(68)\end{array}$ & $\begin{array}{c}40.44 \\
(74) \\
\end{array}$ & $\begin{array}{l}95.08 \\
(175) \\
\end{array}$ & $\begin{array}{c}100 \\
(183) \\
\end{array}$ & North & \\
\hline & 点 & $\begin{array}{c}100 \\
(136)\end{array}$ & $\begin{array}{c}46.32 \\
(63) \\
\end{array}$ & $\begin{array}{l}86.76 \\
(118)\end{array}$ & $\begin{array}{c}44.85 \\
(61)\end{array}$ & $\begin{array}{l}94.12 \\
(128)\end{array}$ & $\begin{array}{l}94.12 \\
(128)\end{array}$ & $\begin{array}{l}97.06 \\
(136)\end{array}$ & $\begin{array}{c}100 \\
(136)\end{array}$ & $\begin{array}{l}97.06 \\
(132)\end{array}$ & $\begin{array}{c}39.71 \\
(54)\end{array}$ & $\begin{array}{c}50.00 \\
(68)\end{array}$ & $\begin{array}{c}22.06 \\
(30)\end{array}$ & $\begin{array}{c}35.29 \\
(48)\end{array}$ & $\begin{array}{c}39.71 \\
(54)\end{array}$ & $\begin{array}{l}97.06 \\
(132)\end{array}$ & $\begin{array}{c}100 \\
(136)\end{array}$ & & South \\
\hline
\end{tabular}

The presence or absence of KIR genes was determined from two Irish cohorts, Northern Ireland (North, $n=186$ ) and Republic of Ireland (South, $n=136$ ). The presence or absence of a KIR gene is indicated by grey and white boxes, respectively. The percentage of individuals in each cohort possessing KIR genes and genotypes was determined, as described in Materials and methods and displayed on the bottom rows and right-hand columns. respectively. The number of individuals possessing a particular KIR gene or genotype is indicated in brackets beside the percentage $(n)$. The classification of genotypes into AA, AB or BB is also indicated (see Materials and methods for more details on classification).

suggested that variation between populations along this dimension may reflect an underlying gradient in the frequency of KIR genes associated with $\mathrm{A}$ and $\mathrm{B}$ haplotypes. To investigate further, A and B genotype frequencies of the total populations were obtained from the literature and from the online database www.allelefrequencies.net, by analysis of KIR gene content (see Materials and methods). Regression analysis of PC1 values and A genotype frequencies shows a strong positive linear relationship $\left(r^{2}=0.859, P\right.$-value $<0.0001$, see Figure $1 b$ ). Conversely, a negative relationship is observed for B haplotypes $\left(r^{2}=0.390, P\right.$-value $<0.0005$, see Figure $1 \mathrm{~b}$ ). This confirms that a large proportion of the variation between populations along the first component reflects variations in the frequency distribution of A and B haplotypes. Analysis of the second component reveals no relationship with $\mathrm{B}$ haplotype frequencies $\left(r^{2}=0.03, P\right.$-value $=0.39$, data not shown $)$. Likewise, no relationship is observed with A haplotypes (data not shown). This shows that variation between populations along the second component is independent of KIR A/B haplotype status. In summary, a major genetic gradient is observed at a global level, which reflects variations in $\mathrm{A} / \mathrm{B}$ haplotype frequencies between populations. Examination of global PC data in Figure 1a suggested that within the European cluster, there is evidence of genetic stratification along a north to south gradient and that both PC1 and PC2 contribute to this. This gradient was confirmed by constructing synthetic contour maps of Europe using ArcView software. Analysis of PC1, which accounts for the vast majority of variation in KIR genes, shows a clear north-south gradient of PC1 values increasing into northern Europe and with values decreasing southwards (see Figure 1c). The Irish population exhibits high PC1 values, similar to other northern Europeans. Spatial autocorrelation was performed to confirm the significance of the gradient and its directionality. A genetic gradient is characterized by 

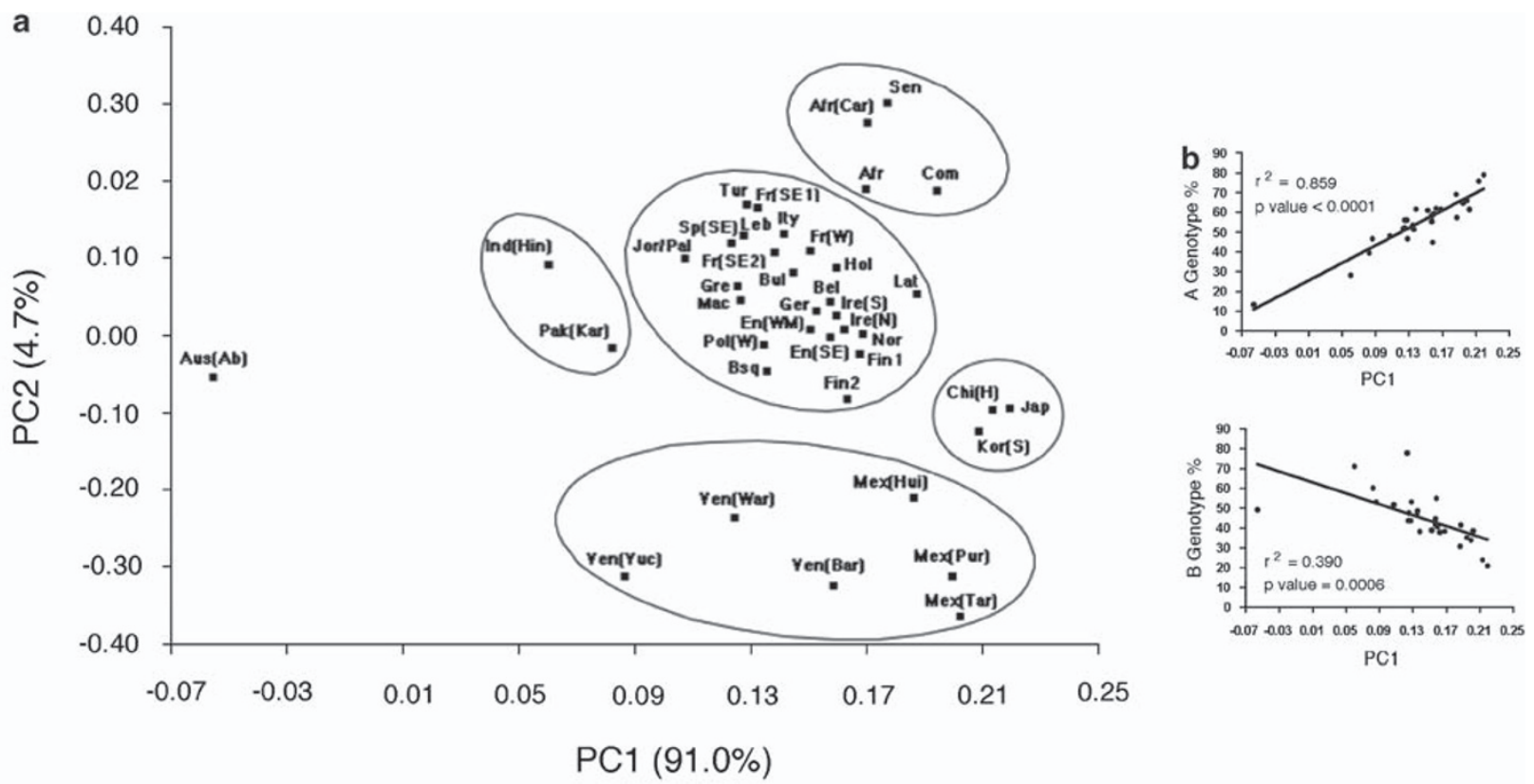

PC1
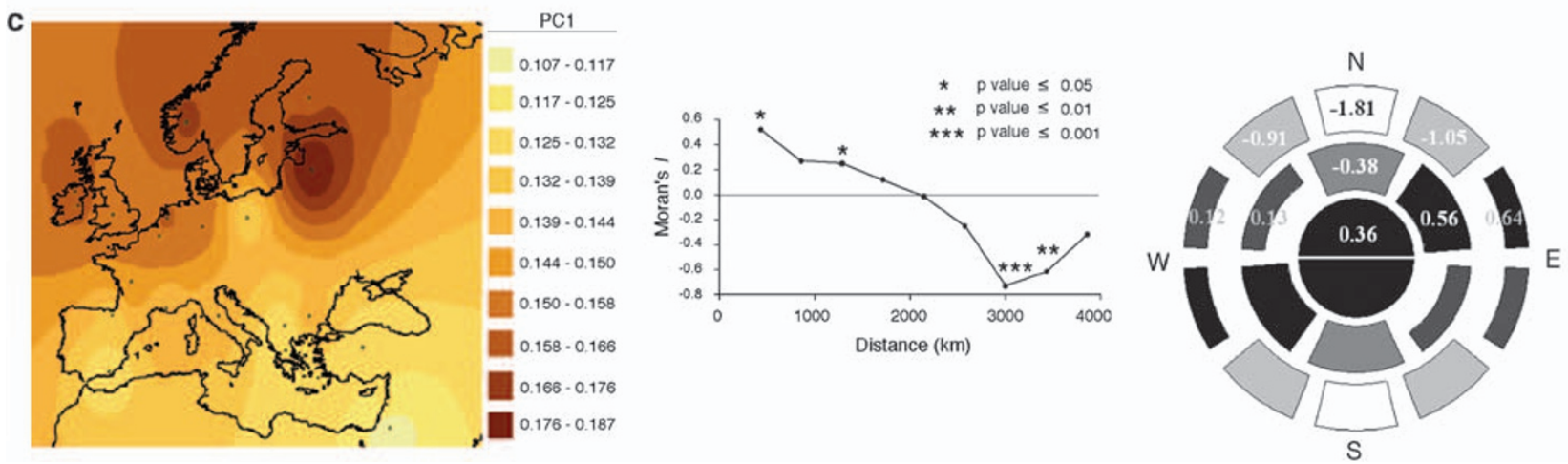

Figure 1 Principal component (PC) analysis of killer cell immunoglobulin-like receptor (KIR) gene frequencies in global and European populations. (a) Forty populations were compared in terms of KIR gene frequencies by PC analysis. Africa (Afr); Afro-Caribean (Afr(Car)); Australian Aborigines (Aus(ab)); Belgium (Bel); Bulgaria (Bul); China Han (Chi; H, Han); Comoros (Com); England (Eng; SE, South-East; W, West Midlands); Finland (Fin); France (Fr; W, West; SE, South-East); Germany (Ger); Greece (Gre); Holland (Hol); Ireland (Ire); Italy (Ity); India (Ind; Hin, Hindus); Japan (Jap); Jordanian Palestinians (Jor/Pal); South Korea (Kor(S)), Latvia (Lat); Lebanon (Leb); Macedonia (Mac); Mexico (Mex; Hui, Huicholes; Pur, Purepecha; Tar, Tarahumara); Norway (Nor); Pakistan (Pak; Kar, Karachi); Poland (Pol); Senegal (Sen); Spain (Sp; Bsq, Basque; SE, South-East); Turkey (Tur); Venzeula (Ven; Bar, Bari, War, Warao; Yuc, Yucpa). Circles indicate different ethnic groups or clusters: Europeans/Middle Eastern, African, SE Asian, Native Americans, Southern Asians, Australian Aboriginals. (b) A and B haplotype frequencies correlate with KIR PC1 values. PC1 values for each population are plotted against their A and B haplotype frequencies. Results of linear regression analyses are indicated on each plot. (c) PC1 values of the populations are plotted on a synthetic map of Europe. Geographical coordinates of populations $(n=23)$ are represented by points. One-dimensional (1D) spatial autocorrelogram displays Moran's $I$ measure of spatial autocorrelation against distance in kilometers $(\mathrm{km})$. The Windrose two-dimensional (2D) correlogram of PC1 values shows the geographical direction of genetic change. Values of Moran's $I$ is indicated in each segment. Full segments indicate that spatial autocorrelation $(P<0.05)$ is statistically significant, whereas half segments are not significant $(P>0.05)$. Dark shading indicates varying degrees of positive spatial autocorrelation, whereas light shading indicates varying degrees of negative spatial autocorrelation. Overall, the $1 \mathrm{D}$ and 2D correlograms are statistically significant.

positive spatial autocorrelation (similarity) between populations within close geographical proximity, and negative spatial autocorrelation (genetic dissimilarity) between populations at far distances apart. One-dimensional (1D) spatial autocorrelation analysis of PC1 values for the KIR genes shows that genetic similarity (Moran's $I>0$ ) is high between populations within close geographical proximity and that genetic similarity decreases with increasing distance $(P<0.05$, Figure 1c). Twodimensional (2D) spatial autocorrelation analysis takes compass bearings into account when calculating Moran's I, to determine the directionality of the genetic gradient.
The Windrose correlogram for PC1 values shows high levels of spatial autocorrelation of KIR genes in a general east to west direction with a decrease observed in a north-south direction over increasing distances (Figure 1c). This shows that populations are similar in an east to west direction and they differ in a north to south direction. This confirms the north-south directionality of the KIR gene gradient in Europe. Although PC2 accounts for $<5 \%$ of the variation among KIR genes, it supported the trend found with evidence of a general south-east to north-west gradient of decreasing PC2 values in Europe (data not shown). 
High frequency of activatory, B haplotype KIR genes in Southern Europe

As A and B KIR genotype frequencies correlate with PC1 values, this analysis suggests that the B haplotype is more common in the south of Europe, whereas the A haplotype is more common in Northern Europe. We therefore examined whether or not individual KIR genes associated with A or B haplotypes showed evidence of stratification in Europe. Two B haplotype defining KIR genes, 2DS2 and 2DL2, exhibit clear north-south gradients in Europe, with a twofold higher gene frequency observed in the south compared with the north of Europe (see Figures 2a and b). These KIRs are inherited in strong linkage disequilibrium with each other. Analysis of another B haplotype KIR, 2DS3, showed a clearly defined south-east to north-west gradient of decreasing gene frequency (Figure 2c) with a twofold difference in frequency observed. The Irish populations exhibits relatively low 2DS2, 2DS3 and 2DL2 frequencies, similar to other northern Europeans. Analysis of 1D spatial autocorrelation confirms that stratification of the 2DS2 in Europe is statistically significant and the gradients and their directions for 2DS2, 2DL2 and 2DS3 are statistically significant by 2D spatial autocorrelation analysis $(P<0.05)$. Together these data are consistent with evidence from PC analysis that B haplotypes are more frequent in Southern Europe and less frequent in the north.

Analysis of other A and B haplotype KIR show some evidence of stratification. The frequency of 2DL3 (a common A haplotype KIR) in Europe is observed to increase in a general south-east to north-west direction (Supplementary Figure S1A). Analysis of the distribution of the homozygous AA genotype indicates that it is increased in Northern Europe (Supplementary Figure S1B). In combination, the distribution of 2DL3 and the AA genotype indicate that $A$ haplotypes are more prevalent in Northern Europe. This finding is consistent with the observed decrease in B haplotypes and associated KIR genes in Northern Europe. 2DS5 is the only B haplotype-associated KIR that tends to increase in frequency in Northern Europe (data not shown). Analysis of 2DL1, 2DS1, 3DL1 and 3DS1 showed no population structure (data not shown and Supplementary Figure S2A for 3DS1 data).

\section{Higher frequency of potent inhibitory KIR ligands in Southern Europe}

Human leukocyte antigen-C1 and HLA-C2 are mutually exclusive epitopes of the HLA-C protein that provide distinct ligands for 2DL3 (including its common variant 2DL2) and 2DL1 inhibitory KIRs, respectively. The HLAC1/2DL3 pairing provides a relatively weak functional inhibitory interaction in contrast to HLA-C2/2DL1 or HLA-C1/2DL2, which are considered to provide relatively strong inhibitory signals to the NK cell. HLA-C1 follows a clear increasing south-east to north-west gradient distribution in Europe (ranges between 41.8 and $81.5 \%$ frequency between north-west and south-east, see Figure 3a). Like other northwestern Europeans, the Irish populations exhibits a high HLA-C1 frequency compared with southeastern Europeans. Spatial autocorrelation confirmed the presence and direction $(P<0.05)$ of a HLA-C1 gradient in Europe (Figure 3a). As expected, HLA-C2 follows an increasing frequency gradient in the opposite direction as HLA-C1, with a threefold frequency difference across Europe (range 15.4-57.3\%, see Figure 3b). The Irish population, similar to other northwestern Europeans, displays a relatively low HLA-C2 frequency.

Human leukocyte antigen-Bw4 is an epitope, which provides a ligand for the 3DL1 inhibitory receptor. It is mutually exclusive with the Bw6 epitope, which does not have any defined NK cell specificity. Although primarily associated with HLA-B, a variant of the Bw4 epitope is expressed by some HLA-A alleles (HLA-A-Bw4). Distribution of HLA-B-Bw4 is quite similar to HLA-C2 as it has a lower frequency in the north and northwest of Europe and a tendency to a higher frequency in Southern Europe (Figure 3c). Analysis of spatial autocorrelation confirms the presence of significant structure of HLA-BBw4 in Europe $(P<0.05)$. Analysis of $2 \mathrm{D}$ spatial autocorrelation confirms the presence of a broad north-south gradient of HLA-B-Bw4 frequency in Europe $(P<0.05)$, consistent with the contour map (Figure 3c). HLA-Bw4 is of particular interest as a subgroup of alleles, those with isoleucine at position 80 (80I), have been implicated in delayed progression in human immunodeficiency virus in epidemiological studies when HLA-B-Bw4-80I is inherited with KIR 3DS1. ${ }^{38}$ HLA-B-Bw4-80I shows strong evidence of stratification in Europe. Frequencies are higher in Southern Europe and decrease northwards (Figure 3d). The Irish, like most northern Europeans, display relatively low frequencies of Bw4-80I. Spatial autocorrelation (1D) confirms the significance of the gradient (see Figure $3 \mathrm{~d}$ ) and its direction $(P<0.05)$. In contrast, HLA-A Bw4-80I follows a general east-west gradient, peaking in Eastern Europe (all HLA-A alleles with the Bw4 epitope are 80I, see Supplementary Figure S2B).

\section{Discussion}

In this study, we have shown considerable variation in KIR gene and HLA class I ligand distribution in Europe. Overall, south and southeastern Europe is a region characterized by high frequencies of B haplotype KIR and KIR ligands, HLA-C2 and Bw4, and a correspondingly lower frequency of A haplotype KIR and HLA-C1. Conversely, north and northwestern Europe is an area of high A haplotype KIR and HLA-C1 frequency but a lower frequency of B haplotype KIR, HLA-C2 and -Bw4. Indeed, the two Irish populations that we typed for this analysis fit the general gradients extremely well. Several studies have shown that NK cell responsiveness is determined by the type of KIR and HLA class I allele combinations inherited by individuals, for example, weaker inhibitory interactions between 2DL3 and HLA-C1 account for the increased functional activities of NK cells in response to viral infection when compared with the stronger inhibitory interactions between 2DL1 and its ligand HLA-C2. ${ }^{10}$ Our data show that 2DL3 and its ligand (HLA-C1) are more common in northwestern Europe compared with the southeast. In contrast, although 2DL1 is found at high frequency throughout Europe, its ligand (HLA-C2) is more common in the southeast than in the north. This shows that a stronger KIR:HLA-C inhibitory system is more prevalent in the southeast of Europe, whereas a less potent inhibitory 

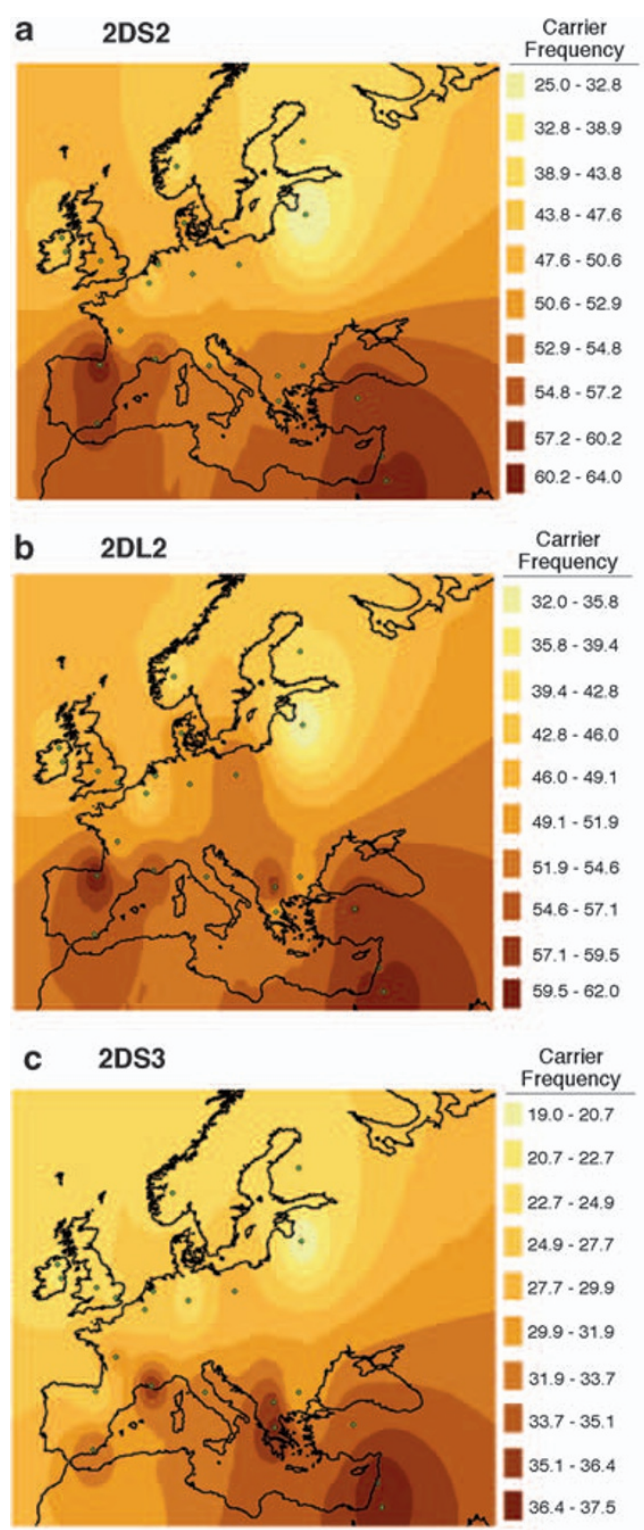
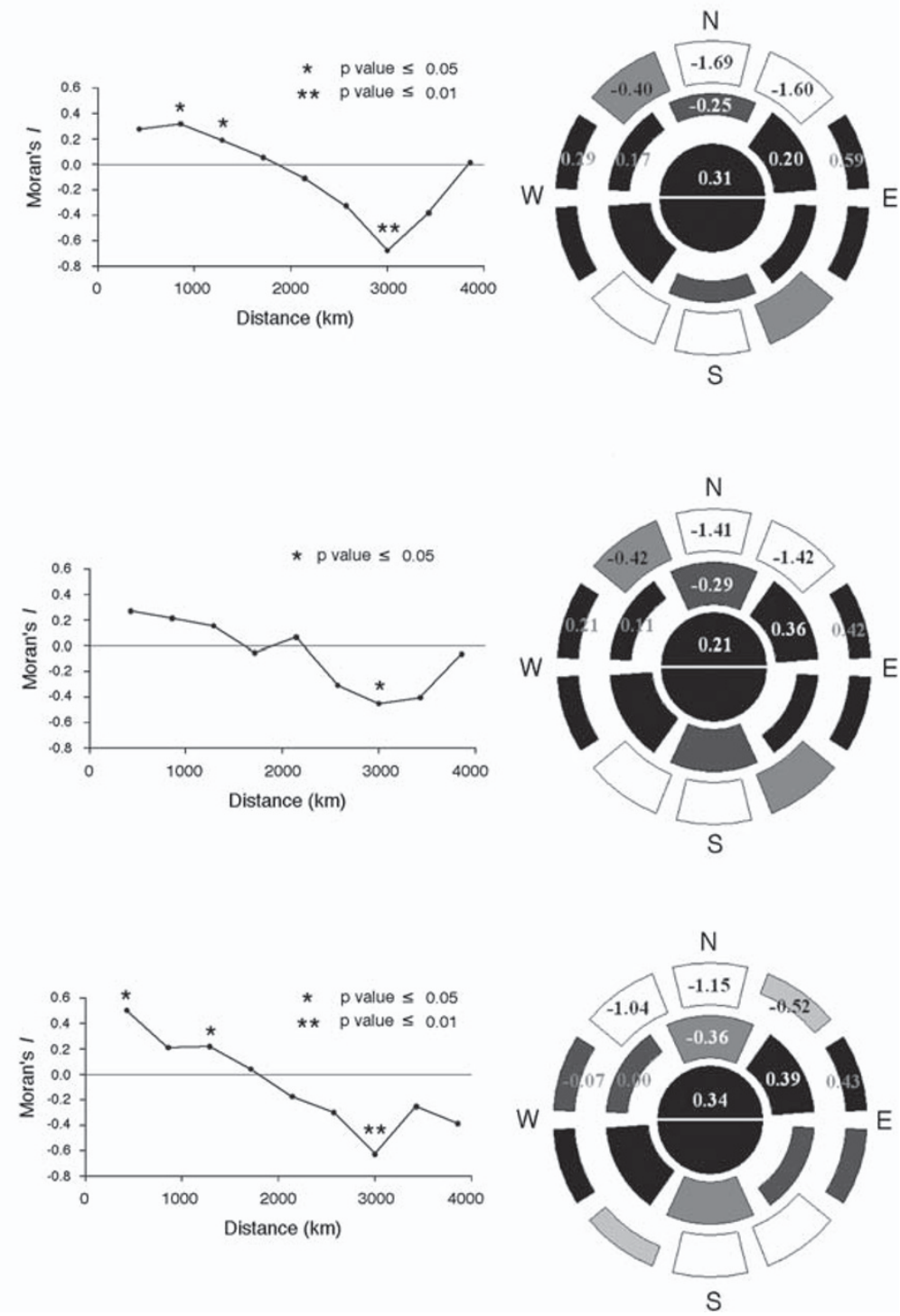

Figure 2 Higher frequency of B haplotype killer cell immunoglobulin-like receptor $(K I R)$ genes in Southern Europe. Synthetic maps of Europe showing 2DS2, 2DL2 and 2DS3 carrier frequencies (\%) are on the left-hand side in panels a, b and c, respectively. Geographical coordinates of populations $(n=23)$ are represented by points. The center figure of each panel shows the Moran's $I$ values for the respective gene against distance in kilometers $(\mathrm{km})$. Overall, the one-dimensional correlogram is statistically significant for 2DS2. The right-hand figures show two-dimensional (2D) spatial autocorrelation values indicating the geographical direction of genetic change. The distance classes for this analysis, from the center are 0-910, 910-2410 and 2410-4710 km for the three annuli, respectively. Moran's I values are indicated in each segment. Full segments indicate that spatial autocorrelation $(P<0.05)$ is statistically significant, whereas half segments are not significant $(P>0.05)$. Dark shading indicates varying degrees of positive spatial autocorrelation, whereas light shading indicates varying degrees of negative spatial autocorrelation. Overall, all 2D correlograms were statistically significant.

system is present in the northwest. Furthermore, although the inhibitory KIR, 3DL1, shows little structure in Europe (highly frequent throughout Europe), its ligand (HLA-B-Bw4) is more common in Southern Europe. Several studies have shown that HLA-Bw4 is a strong inhibitory ligand for 3DL1 on NK cells. ${ }^{14,39}$ Overall, this indicates that NK cell-responsive phenotypes in north-northwestern Europe are increased in frequency as a consequence of the predominance of the relatively weak 2DL3:HLA-C1 inhibitory system, whereas this phenotype is lower in frequency in the south of Europe because of the increase prevalence of the more potent HLA-C2 and HLA-B-Bw4 inhibitory system.
This finding is significant as it shows genetic stratification of epistatic KIR:HLA receptor systems, which allow 'functional gradients' likely to affect human immunity, in different European populations to be defined.

There are several lines of evidence in support of processes of coevolution between KIR genes and their HLA class I ligands. ${ }^{14,17,20}$ A recent study of KIR diversity showed a clear negative correlation between activatory KIR (3DS1, 2DS1 and 2DS2) and their ligands (HLA-Bw4, -C2 and -C1), and a level of positive correlation between inhibitory KIR (3DL1 and 2DL3) and their ligands (HLA-Bw4 and -C1) across global populations. In support of the findings of Single et al., ${ }^{20}$ we found 

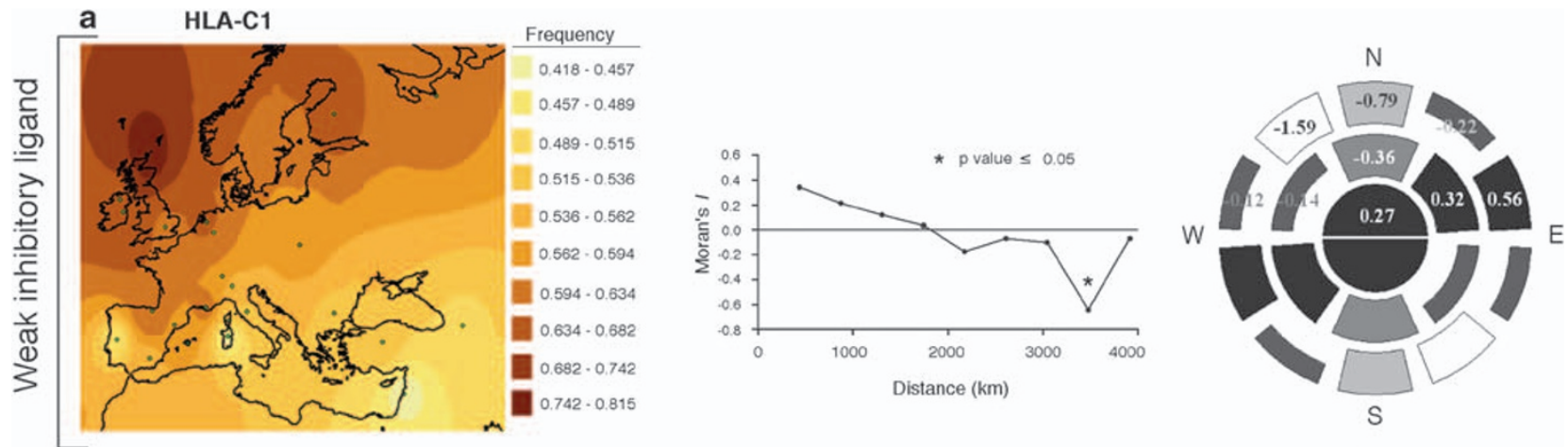

b HLA-C2
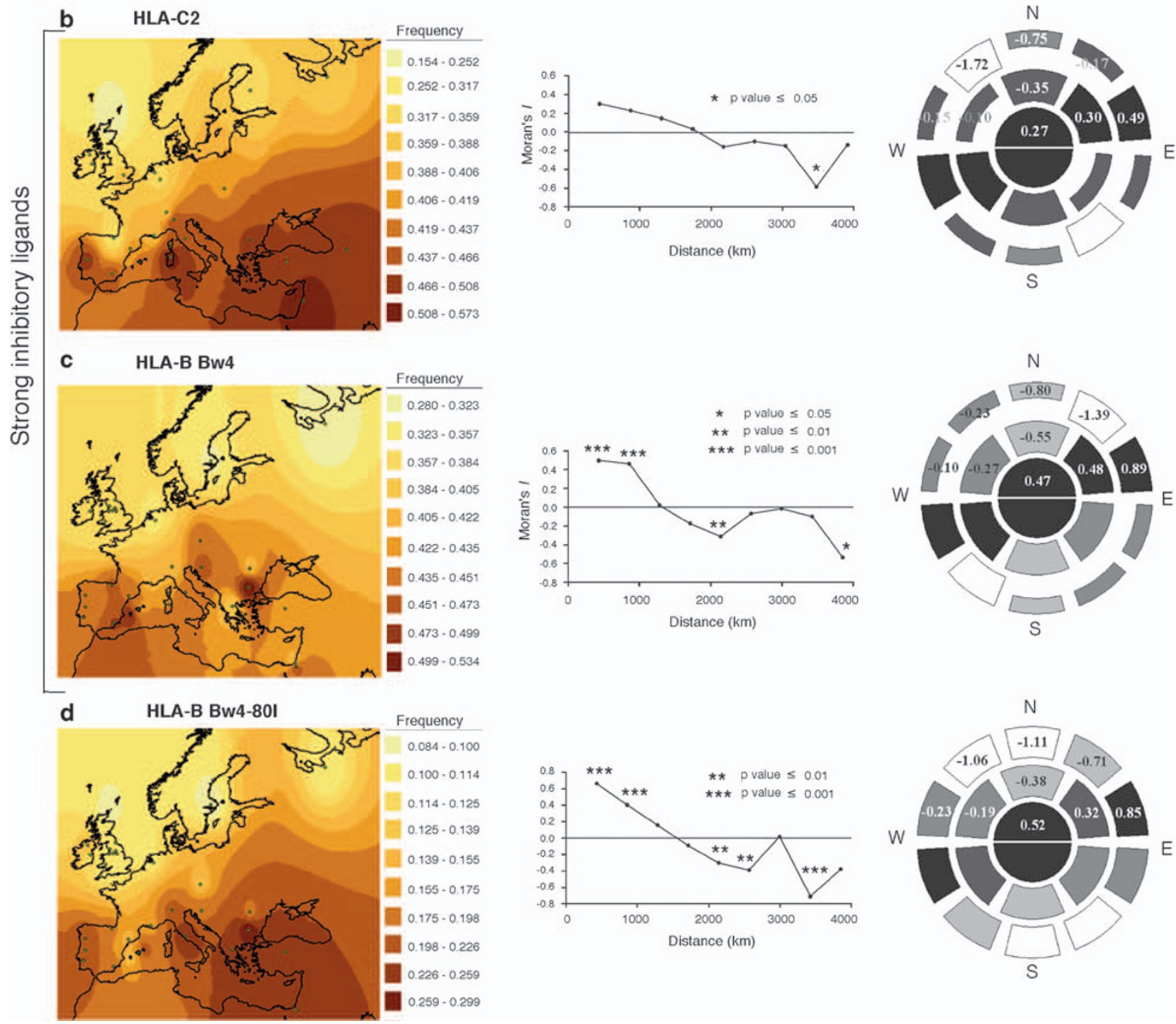

Figure 3 Higher frequency of potent inhibitory killer cell immunoglobulin-like receptor (KIR) ligands in Southern Europe. Synthetic maps of Europe showing human leukocyte antigen (HLA)-C1, HLA-C2, HLA-B-Bw4 and HLA-B-Bw4-80I gene frequencies (\%) are on the left-hand side in panels $\mathbf{a}, \mathbf{b}, \mathbf{c}$ and $\mathbf{d}$, respectively. Geographical coordinates of populations $(n=22$ for HLA-C, $n=30$ for HLA-B) are represented by points. The center figure of each panel shows the Moran's I values for the respective gene against distance in kilometers (km). Overall, the one-dimensional correlograms for HLA-B are statistically significant. The right-hand figure shows two-dimensional (2D) spatial autocorrelation values indicating the geographical direction of genetic change. The distance classes for HLA-C are, from the center, 0-915, 915-2300 and 2300-4355 km. The distance classes for HLA-B are, from the center, $0-910,910-2340$ and $2340-4470 \mathrm{~km}$. For the 2D correlograms, Moran's $I$ values are indicated in each segment. Full segments indicate that spatial autocorrelation $(P<0.05)$ is statistically significant, whereas half segments are not significant $(P>0.05)$. Dark shading indicates varying degrees of positive spatial autocorrelation, whereas light shading indicates varying degrees of negative spatial autocorrelation. Overall, all 2D correlograms are statistically significant. 
distinct genetic gradients with the inhibitory 2DL3 KIR and its ligand HLA-C1 observed together at high frequencies in northwestern Europe. In contrast, the activatory 2DS2 receptor is present at lower frequencies in regions where its ligand (HLA-C1) reaches high frequency in Europe, and is higher in areas where its ligand is reduced in frequency. However, we also found exceptions to these general trends; no correlation between the inhibitory receptor 3DL1 and its HLA-BBw4 ligand is evident, and both HLA-C1 and 2DS2 are found together at high frequency in the Basque population of Northern Spain. Although the distribution of 3DS1 in Europe is not clearly defined, there is evidence of a weak east to west gradient in Europe, where 3DS1 is more prominent in Western Europe (Supplementary Figure S2A). Previous analysis of 3DS1 and HLA-BBw4 globally showed a negative correlation between the two and this correlation was stronger when focusing on HLA-B-Bw4-80I. In contrast, comparison of 3DS1 with HLA-B-Bw4 or HLA-B-Bw4-80I in Europe shows very little positive or negative correlation (Figures $2 \mathrm{c}$ and $\mathrm{d}$ and Supplementary Figure S2A). However, HLA-Bw480I encoded by polymorphisms at the HLA-A locus follows an east-west gradient in Europe and is generally higher in areas of low 3DS1 frequency (Supplementary Figure S2B). This may suggest a possible negative correlation between 3DS1 and Bw4-80I encoded by HLA-A.

Stratification of KIR and HLA in Europe is consistent with coevolution between these two sets of genes and supports findings in the literature providing evidence for natural selection as a major force in shaping KIR diversity worldwide. ${ }^{14,17,18,20}$ However, it is very difficult in this type of analysis to distinguish between processes of natural selection and demographic history. Many of the gradients observed for KIR and HLA in this study are similar to the distribution of $\mathrm{Y}$ chromosome and mitochondrial DNA markers in Europe that have been attributed to population movements and founder effects. $^{40-42}$ Indeed, numerous studies have shown a close relationship between the Irish, Basques and other populations along the extreme northwestern edge of Europe. However, there are striking differences between the Irish and the Basques when looking at KIR genes that are inconsistent with these previous genetic studies. ${ }^{40,41}$ In the case of 2DS2, 2DL2 and HLA-Bw4 gene frequencies, the Basque population falls into the southern European group, a clear deviation from what is usually observed in Europe. Demographics do not explain these differences, and although local selective effects on A and B haplotypes or their components in the Basque population might explain these trends, the data may reflect natural selection acting to increase $B$ haplotype KIR in Southern Europe and/or increase A haplotype KIR in Northern Europe.

Before this study, the frequency of the human immunodeficiency virus-resistance mutation, CCR5$\Delta 32$, represented one of the few clearly defined northsouth genetic gradients of an immune-related gene in Europe. It has been argued extensively that the elevated frequency of this allele in Northern Europe compared with the south represents a signature of natural selection acting on CCR5- $\Delta 32$, in response to either bubonic plague during the $1300 \mathrm{~s} \mathrm{AD}^{43}$ or as a more recent theory proposes, in response to prolonged exposure to smallpox virus. ${ }^{44}$ Notably, disease models suggest that certain KIR/HLA combinations that favor NK cell activation improve resistance/clearance of viral infections, for example, 3DS1 and Bw4-80I are associated with delayed progression of human immunodeficiency virus infection in patients. In vitro, the 2DL3:HLA-C1 genotype is associated with more potent activation of NK cells in response to influenza $A$ than is the 2DL1:HLA-C2 genotype. ${ }^{10}$ In this study, we have found high 2DL3:HLA-C1 in Northern Europe and high 2DL1:HLA-C2 in Southern Europe. The functional significance of KIR and HLA variation, coupled to the contrasting disease histories in Europe as a selective pressure, for example, high incidence of intense smallpox epidemics throughout Northern Europe, offers a possible explanation for the observed north-south KIR gradients (or possibly HLA-B-Bw4) in modern-day Europeans. Thus, there may have been historical selective pressures towards an increase in KIR:HLA combinations that were more effective in controlling infections and promoting survival in different regions of Europe.

Although KIR/HLA coevolution and population history is of considerable scientific interest, these processes also significantly affect human health and survival. It is currently believed that KIR/HLA class I ligand combinations, which confer high inhibition to NK cells, are protective in autoimmunity, whereas combinations that confer less inhibition and more activation of NK cells appear to contribute to development of certain autoimmune conditions, for example, 2DS2 in the presence of its ligand, HLA-C1, has been implicated in an array of autoimmune diseases, including susceptibility to type I diabetes, psoriatic arthritis and rheumatoid vaculitis. ${ }^{45-49}$ In terms of disease epidemiology, the KIR and HLA class I gradients observed in Europe may be of particular importance as several autoimmune diseases such as type I diabetes and primary sclerosing cholangitis are known to be elevated in frequency in Northern compared with Southern Europe. ${ }^{50,51}$ In both cases, the presence of HLA-C1 (weak inhibitory 2DL2/3 ligand), which we found to be elevated in northwestern Europe, has been reported to be associated with disease susceptibility. ${ }^{46,48,49}$ On the other hand, HLA-C2 (strong inhibitory ligand for 2DL1) is more frequent in Southern Europe and is thought to confer protection against these diseases. In the case of primary sclerosing cholangitis, HLA-Bw4 (strong inhibitory 3DL1 ligand), which is more common in Southern Europe, is also reported as a protective phenotype, though lacking this KIR ligand (no inhibition through 3DL1) predisposes to the disease. Hence, the distribution of ligands for KIR in Europe correlates strongly with the epidemiology of these diseases. Susceptibility genotypes $(\mathrm{C} 1+, \mathrm{Bw} 4-)$ are increased in Northern Europe where these diseases are common, and protective genotypes $(\mathrm{C} 2 / \mathrm{C} 2, \mathrm{Bw} 4+)$ are more common in Southern Europe where disease incidence is lower. In Northern Europe, the weaker inhibitory KIR:HLA background may allow a strong effect of activatory KIR on NK cells, for example, 2DS2, to be manifested in increased susceptibility to certain autoimmune diseases. In conclusion, the presence of genetic gradients and genetic substructure in Europeans has undergone extensive investigation in recent years. A major question to emerge from this was whether genetic 
stratification gives rise to phenotypic or functional differences between Europeans in different regions of the continent. We have shown that within the immune system, the epistatic KIR:HLA receptor system follows clear 'functional gradients' in Europe. These gradients are likely to have emerged because of processes of both natural selection and demographic history and have culminated in distinct immunological characteristics in northern and southern Europeans.

\section{Materials and methods}

\section{KIR typing}

Blood donors were recruited from the Blood Transfusion Services of Belfast City Hospital, Belfast, Northern Ireland $(n=183)$, and St James's Hospital, Dublin, Republic of Ireland $(n=136)$. Mononuclear cells were isolated from buffy coats using standard Ficoll gradient centrifugation. Genomic DNA was extracted from cells using the salting-out method. ${ }^{52}$ PCR-SSOP was carried out to confirm the presence or absence of KIR genes in Northern and Republic of Ireland populations as previously described. KIR gene and genotype frequencies of an additional ${ }^{36}$ global population (4218 individuals from 38 different studies) were obtained from the published literature (35 populations ${ }^{31-33,46,48,49,53-71}$ ) and from an online database www.allelefrequencies.net. ${ }^{72}$

Genotypes were classified as follows: the absence of 2DL2, 2DL5, 3DS1, 2DS1, 2DS2, 2DS3 or 2DS5 indicates that an individual is homozygous for the A genotype (that is, AA). If any of 2DL2, 2DL5, 3DS1, 2DS1, 2DS2, 2DS3 or 2DS5 are present and each of 3DL1, 2DL1, 2DL3 and 2DS4 are also present, then such individuals are considered heterozygous for $A$ and $B$ (that is, AB). An individual is considered homozygous for B if they lack either of 3DL1, 2DL1, 2DL3 or 2DS4.

\section{HLA class I typing}

The presence or absence of HLA class I ligands for KIR was investigated in both Northern $(n=97)$ and Republic of Ireland $(n=135)$ cohorts using a previously described SSOP method. ${ }^{62}$ The following ligands were distinguished: HLA-C1, -C2, HLA-B-Bw4 and HLA-B-Bw480I. HLA class I allele frequencies in European populations were determined using HLA class I subtyping data obtained from the literature (for HLA-C: see references, from Bendukidze and Ivaskova ${ }^{73}$ to Ferrara et al. $;^{90}$ for HLA-A and B: see references, from Comas et al. ${ }^{76}$ to Evseeva et al., ${ }^{78}$ Ferrara et al., ${ }^{80}$ Meyer et al., ${ }^{84}$ SaruhanDireskeneli and Ugar, ${ }^{87}$ Tonk et al., ${ }^{88}$ and from references Cecuk et al. ${ }^{91}$ to Zahlavova ${ }^{101}$ and the online databases www.allelefrequencies.net, and www.ncbi.nlm.nih. gov $/ \mathrm{gv} / \mathrm{mhc} /$ ihwg.cgi? $\mathrm{cmd}=$ page\&page = AnthroMain . Using these data, KIR ligand frequencies were defined using strict classification criteria as detailed in Supplementary Table S1. In brief, the following ligands for KIR were considered: HLA-C1, and -C2 $(n=22,3398$ individuals); HLA-B-Bw4 and HLA-B-Bw4-80I $(n=30,25158$ individuals); and HLA-A-Bw4 $(n=32,26598$ individuals). Carrier frequencies were converted to allele frequencies using the Bernstein equation ( $F=1-$ (sqrt $(1-f))$ ) where necessary. Alleles that are rare and/or not routinely typed for in Caucasians populations were omitted from analysis as indicated.

\section{Statistical analysis}

Principal component analysis using KIR gene frequency data (2DL1, 2DL3, 2DL3, 2DS1, 2DS2, 2DS3, 2DS4, 2DS5, 3DL1, 3DS1) from a total of 38 populations, including the Irish data generated as part of this study, was carried out using MINITAB software. Linear regression analysis of PC values and KIR genotype frequencies was carried out using GraphPad PRISM software. PC values were viewed graphically using ARCVIEW (Version 3.2). Both PC values and geographical coordinates of European populations were imported into ARCVIEW and contour maps were constructed using the spatial analyst extension of the program. Significance and directionality of genetic gradients were assessed by spatial autocorrelation using PASSAGE software (Rosenberg, MS, Version 1.1, Arizona State University Tempe, AZ, USA). PC values and geographical coordinates of European populations were imported into PASSAGE and distance/ angles and distance classes were created. The presence of geographical gradients was initially assessed statistically by $1 \mathrm{D}$ spatial autocorrelation using Moran's I statistic, which measures genetic similarity of populations within distinct distance classes (kilometers). Positive spatial autocorrelation, that is, genetic similarity, is indicated by Moran's $I$ values $>0$, and negative spatial autocorrelation, that is, genetic dissimilarity, is indicated by Moran's $I$ values $<0$. A genetic gradient is characterized by statistically significant positive spatial autocorrelation between populations within close geographical proximity, and statistically significant negative spatial autocorrelation between populations at far distances apart. The directionality of gradients was assessed statistically by 2D spatial autocorrelation, which takes compass bearings into consideration when measuring genetic similarity within distance classes. The distance classes represented by the first, second and third annuli of a Windrose correlogram are defined in each legend. Values of Moran's I are indicated in each segment. Full segments indicate that spatial autocorrelation is statistically significant $(P<0.05)$, whereas half segments are not significant $(P>0.05)$. Dark shading indicates varying degrees of positive spatial autocorrelation, whereas light shading indicates varying degrees of negative spatial autocorrelation. Similar analysis was carried out for KIR and HLA genes.

\section{Conflict of interest}

The authors declare no conflict of interest.

\section{Acknowledgements}

We thank Professor Dan Bradley and Dr David Mitchell for helpful discussion and advice. This work was supported by an Ireland-Northern Ireland Cooperation grant funded jointly by the Irish Health Research Board and the Northern Ireland R\&D Office.

\section{References}

1 Biron CA, Nguyen KB, Pien GC, Cousens LP, Salazar-Mather TP. Natural killer cells in antiviral defense: function and 
regulation by innate cytokines. Annu Rev Immunol 1999; 17: 189-220.

2 Cerwenka A, Lanier LL. Natural killer cells, viruses and cancer. Nat Rev Immunol 2001; 1: 41-49.

3 O'Connor GM, Hart OM, Gardiner CM. Putting the natural killer cell in its place. Immunology 2006; 117: 1-10.

4 Gardiner CM. Killer cell immunoglobulin-like receptors on NK cells: the how, where and why. Int J Immunogenet 2008; 35: $1-8$.

5 Lanier LL. Activating and inhibitory NK cell receptors. Adv Exp Med Biol 1998; 452: 13-18.

6 Vilches C, Parham P. KIR: diverse, rapidly evolving receptors of innate and adaptive immunity. Annu Rev Immunol 2002; 20: 217-251.

7 Colonna M, Borsellino G, Falco M, Ferrara GB, Strominger JL. HLA-C is the inhibitory ligand that determines dominant resistance to lysis by NK1- and NK2-specific natural killer cells. Proc Natl Acad Sci USA 1993; 90: 12000-12004.

8 Wagtmann N, Rajagopalan S, Winter CC, Peruzzi M, Long EO. Killer cell inhibitory receptors specific for HLA-C and HLA-B identified by direct binding and by functional transfer. Immunity 1995; 3: 801-809.

9 Gumperz JE, Litwin V, Phillips JH, Lanier LL, Parham P. The Bw4 public epitope of HLA-B molecules confers reactivity with natural killer cell clones that express NKB1, a putative HLA receptor. J Exp Med 1995; 181: 1133-1144.

10 Ahlenstiel G, Martin MP, Gao X, Carrington M, Rehermann B. Distinct KIR/HLA compound genotypes affect the kinetics of human antiviral natural killer cell responses. J Clin Invest 2008; 118: 1017-1026.

11 Alter G, Martin MP, Teigen N, Carr WH, Suscovich TJ, Schneidewind A et al. Differential natural killer cell-mediated inhibition of HIV-1 replication based on distinct KIR/HLA subtypes. J Exp Med 2007; 204: 3027-3036.

12 Moesta AK, Norman PJ, Yawata M, Yawata N, Gleimer M, Parham P. Synergistic polymorphism at two positions distal to the ligand-binding site makes KIR2DL2 a stronger receptor for HLA-C than KIR2DL3. J Immunol 2008; 180: 3969-3979.

13 Winter CC, Gumperz JE, Parham P, Long EO, Wagtmann N. Direct binding and functional transfer of NK cell inhibitory receptors reveal novel patterns of HLA-C allotype recognition. J Immunol 1998; 161: 571-577.

14 Yawata M, Yawata N, Draghi M, Little AM, Partheniou F, Parham P. Roles for HLA and KIR polymorphisms in natural killer cell repertoire selection and modulation of effector function. I Exp Med 2006; 203: 633-645.

15 Biassoni R, Pessino A, Malaspina A, Cantoni C, Bottino C, Sivori $\mathrm{S}$ et al. Role of amino acid position 70 in the binding affinity of p50.1 and p58.1 receptors for HLA-Cw4 molecules. Eur I Immunol 1997; 27: 3095-3099.

16 Stewart CA, Laugier-Anfossi F, Vely F, Saulquin X, Riedmuller J, Tisserant A et al. Recognition of peptide-MHC class I complexes by activating killer immunoglobulin-like receptors. Proc Natl Acad Sci USA 2005; 102: 13224-13229.

17 Norman PJ, Abi-Rached L, Gendzekhadze K, Korbel D, Gleimer M, Rowley $\mathrm{D}$ et al. Unusual selection on the KIR3DL1/S1 natural killer cell receptor in Africans. Nat Genet 2007; 39: 1092-1099.

18 Norman PJ, Cook MA, Carey BS, Carrington CV, Verity DH, Hameed $\mathrm{K}$ et al. SNP haplotypes and allele frequencies show evidence for disruptive and balancing selection in the human leukocyte receptor complex. Immunogenetics 2004; 56: 225-237.

19 Parham P. MHC class I molecules and KIRs in human history, health and survival. Nat Rev Immunol 2005; 5: 201-214.

20 Single RM, Martin MP, Gao X, Meyer D, Yeager M, Kidd JR et al. Global diversity and evidence for coevolution of KIR and HLA. Nat Genet 2007; 39: 1114-1119.

21 Hiby SE, Walker JJ, O'Shaughnessy K M, Redman CW, Carrington $\mathrm{M}$, Trowsdale $\mathrm{J}$ et al. Combinations of maternal KIR and fetal HLA-C genes influence the risk of preeclampsia and reproductive success. J Exp Med 2004; 200: 957-965.
22 Parham P. NK cells and trophoblasts: partners in pregnancy. I Exp Med 2004; 200: 951-955.

23 Trowsdale J, Moffett A. NK receptor interactions with MHC class I molecules in pregnancy. Semin Immunol 2008; 20: 317-320.

24 Hanna J, Goldman-Wohl D, Hamani Y, Avraham I, Greenfield C, Natanson-Yaron S et al. Decidual NK cells regulate key developmental processes at the human fetal-maternal interface. Nat Med 2006; 12: 1065-1074.

25 Hsu KC, Chida S, Geraghty DE, Dupont B. The killer cell immunoglobulin-like receptor (KIR) genomic region: geneorder, haplotypes and allelic polymorphism. Immunol Rev 2002; 190: 40-52.

26 Trowsdale J, Barten R, Haude A, Stewart CA, Beck S, Wilson MJ. The genomic context of natural killer receptor extended gene families. Immunol Rev 2001; 181: 20-38.

27 Gardiner CM, Guethlein LA, Shilling HG, Pando M, Carr WH, Rajalingam R et al. Different NK cell surface phenotypes defined by the DX9 antibody are due to KIR3DL1 gene polymorphism. J Immunol 2001; 166: 2992-3001.

28 Shilling HG, Guethlein LA, Cheng NW, Gardiner CM, Rodriguez R, Tyan D et al. Allelic polymorphism synergizes with variable gene content to individualize human KIR genotype. J Immunol 2002; 168: 2307-2315.

29 Pascal V, Stulberg MJ, Anderson SK. Regulation of class I major histocompatibility complex receptor expression in natural killer cells: one promoter is not enough!. Immunol Rev 2006; 214: 9-21.

30 Middleton D, Meenagh A, Moscoso J, Arnaiz-Villena A. Killer immunoglobulin receptor gene and allele frequencies in Caucasoid, Oriental and Black populations from different continents. Tissue Antigens 2008; 71: 105-113.

31 Toneva M, Lepage V, Lafay G, Dulphy N, Busson M, Lester S et al. Genomic diversity of natural killer cell receptor genes in three populations. Tissue Antigens 2001; 57: 358-362.

32 Yawata M, Yawata N, McQueen KL, Cheng NW, Guethlein LA, Rajalingam $\mathrm{R}$ et al. Predominance of group A KIR haplotypes in Japanese associated with diverse NK cell repertoires of KIR expression. Immunogenetics 2002; 54: 543-550.

33 Gendzekhadze K, Norman PJ, Abi-Rached L, Layrisse Z, Parham P. High KIR diversity in Amerindians is maintained using few gene-content haplotypes. Immunogenetics 2006; 58 : 474-480.

34 Rayes R, Bazarbachi A, Khazen G, Sabbagh A, Zaatari G, Mahfouz R. Natural killer cell immunoglobulin-like receptors (KIR) genotypes in two Arab populations: will KIR become a genetic landmark between nations? Mol Biol Rep 2008; 35: 225-229.

35 Bauchet M, McEvoy B, Pearson LN, Quillen EE, Sarkisian T, Hovhannesyan $\mathrm{K}$ et al. Measuring European population stratification with microarray genotype data. Am J Hum Genet 2007; 80: 948-956.

36 Lao O, Lu TT, Nothnagel M, Junge O, Freitag-Wolf S, Caliebe A et al. Correlation between genetic and geographic structure in Europe. Curr Biol 2008; 18: 1241-1248.

37 Seldin MF, Shigeta R, Villoslada P, Selmi C, Tuomilehto J, Silva G et al. European population substructure: clustering of northern and southern populations. PLoS Genet 2006; 2: e143.

38 Martin MP, Gao X, Lee JH, Nelson GW, Detels R, Goedert JJ et al. Epistatic interaction between KIR3DS1 and HLA-B delays the progression to AIDS. Nat Genet 2002; 31: 429-434.

39 O'Connor GM, Guinan KJ, Cunningham RT, Middleton D, Parham P, Gardiner CM. Functional polymorphism of the KIR3DL1/S1 receptor on human NK cells. J Immunol 2007; 178: 235-241.

40 Hill EW, Jobling MA, Bradley DG. Y-chromosome variation and Irish origins. Nature 2000; 404: 351-352.

41 McEvoy B, Richards M, Forster P, Bradley DG. The Longue Duree of genetic ancestry: multiple genetic marker systems and Celtic origins on the Atlantic facade of Europe. Am J Hum Genet 2004; 75: 693-702. 
42 Barbujani G, Bertorelle G. Genetics and the population history of Europe. Proc Natl Acad Sci USA 2001; 98: 22-25.

43 Stephens JC, Reich DE, Goldstein DB, Shin HD, Smith MW, Carrington $\mathrm{M}$ et al. Dating the origin of the CCR5-Delta32 AIDS-resistance allele by the coalescence of haplotypes. Am J Hum Genet 1998; 62: 1507-1515.

44 Galvani AP, Slatkin M. Evaluating plague and smallpox as historical selective pressures for the CCR5-Delta 32 HIVresistance allele. Proc Natl Acad Sci USA 2003; 100: 15276-15279.

45 Yen JH, Moore BE, Nakajima T, Scholl D, Schaid DJ, Weyand $\mathrm{CM}$ et al. Major histocompatibility complex class I-recognizing receptors are disease risk genes in rheumatoid arthritis. J Exp Med 2001; 193: 1159-1167.

46 Karlsen TH, Boberg KM, Olsson M, Sun JY, Senitzer D, Bergquist A et al. Particular genetic variants of ligands for natural killer cell receptors may contribute to the HLA associated risk of primary sclerosing cholangitis. I Hepatol 2007; 46: 899-906.

47 Nelson GW, Martin MP, Gladman D, Wade J, Trowsdale J, Carrington M. Cutting edge: heterozygote advantage in autoimmune disease: hierarchy of protection/susceptibility conferred by HLA and killer Ig-like receptor combinations in psoriatic arthritis. J Immunol 2004; 173: 4273-4276.

48 Nikitina-Zake L, Rajalingham R, Rumba I, Sanjeevi CB. Killer cell immunoglobulin-like receptor genes in Latvian patients with type 1 diabetes mellitus and healthy controls. Ann NY Acad Sci 2004; 1037: 161-169.

49 van der Slik AR, Koeleman BP, Verduijn W, Bruining GJ, Roep BO, Giphart MJ. KIR in type 1 diabetes: disparate distribution of activating and inhibitory natural killer cell receptors in patients versus HLA-matched control subjects. Diabetes 2003; 52: 2639-2642.

50 Bach JF. The effect of infections on susceptibility to autoimmune and allergic diseases. $N$ Engl J Med 2002; 347: 911-920.

51 Schrumpf E, Boberg KM. Epidemiology of primary sclerosing cholangitis. Best Pract Res Clin Gastroenterol 2001; 15: 553-562.

52 Miller SA, Dykes DD, Polesky HF. A simple salting out procedure for extracting DNA from human nucleated cells. Nucleic Acids Res 1988; 16: 1215.

53 Becker S, Tonn T, Fussel T, Uhrberg M, Bogdanow M, Seifried $\mathrm{E}$ et al. Assessment of killer cell immunoglobulin-like receptor expression and corresponding HLA class I phenotypes demonstrates heterogenous KIR expression independent of anticipated HLA class I ligands. Hum Immunol 2003; 64: 183-193.

54 Bontadini A, Testi M, Cuccia MC, Martinetti M, Carcassi C, Chiesa A et al. Distribution of killer cell immunoglobulin-like receptors genes in the Italian Caucasian population. J Transl Med 2006; 4: 44.

55 Cook MA, Moss PA, Briggs DC. The distribution of 13 killer-cell immunoglobulin-like receptor loci in UK blood donors from three ethnic groups. Eur J Immunogenet 2003; 30: 213-221.

56 Denis L, Sivula J, Gourraud PA, Kerdudou N, Chout R, Ricard C et al. Genetic diversity of KIR natural killer cell markers in populations from France, Guadeloupe, Finland, Senegal and Reunion. Tissue Antigens 2005; 66: 267-276.

57 Frassati C, Touinssi M, Picard C, Segura M, Galicher V, Papa $\mathrm{K}$ et al. Distribution of killer-cell immunoglobulin-like receptor (KIR) in Comoros and Southeast France. Tissue Antigens 2006; 67: 356-367.

58 Gutierrez-Rodriguez ME, Sandoval-Ramirez L, Diaz-Flores M, Marsh SG, Valladares-Salgado A, Madrigal JA et al. KIR gene in ethnic and Mestizo populations from Mexico. Hum Immunol 2006; 67: 85-93.

59 Jiang K, Zhu FM, Lv QF, Yan LX. Distribution of killer cell immunoglobulin-like receptor genes in the Chinese Han population. Tissue Antigens 2005; 65: 556-563.

60 Luszczek W, Majorczyk E, Nowak I, Pawlik A, Jasek M, Wisniewski A et al. Inhibitory and activatory KIR gene frequencies in the Polish population. Int J Immunogenet 2006; 33: $167-170$

61 Mahfouz R, Rayes R, Mahfoud Z, Bazarbachi A, Zaatari G. Distribution of killer cell immunoglobulin-like receptors genotypes in the Lebanese population. Tissue Antigens 2006; 68: 66-71.

62 Middleton D, Halfpenny I, Meenagh A, Williams F, Sivula J, Tuomilehto-Wolf E. Investigation of KIR gene frequencies in type 1 diabetes mellitus. Hum Immunol 2006; 67: 986-990.

63 Middleton D, Meenagh A, Sleator C, Gourraud PA, Ayna T, Tozkir $\mathrm{H}$ et al. No association of KIR genes with Behcet's disease. Tissue Antigens 2007; 70: 435-438.

64 Middleton D, Vilchez JR, Cabrera T, Meenagh A, Williams F, Halfpenny I et al. Analysis of KIR gene frequencies in HLA class I characterised bladder, colorectal and laryngeal tumours. Tissue Antigens 2007; 69: 220-226.

65 Naumova E, Mihaylova A, Stoitchkov K, Ivanova M, Quin L, Toneva M. Genetic polymorphism of NK receptors and their ligands in melanoma patients: prevalence of inhibitory over activating signals. Cancer Immunol Immunother 2005; 54: $172-178$

66 Niokou D, Spyropoulou-Vlachou M, Darlamitsou A, Stavropoulos-Giokas C. Distribution of killer cell immunoglobulinlike receptors in the Greek population. Hum Immunol 2003; 64: 1167-1176.

67 Norman PJ, Carrington CV, Byng M, Maxwell LD, Curran MD, Stephens HA et al. Natural killer cell immunoglobulinlike receptor (KIR) locus profiles in African and South Asian populations. Genes Immun 2002; 3: 86-95.

68 Norman PJ, Stephens HA, Verity DH, Chandanayingyong D, Vaughan RW. Distribution of natural killer cell immunoglobulin-like receptor sequences in three ethnic groups. Immunogenetics 2001; 52: 195-205.

69 Rajalingam R, Krausa P, Shilling HG, Stein JB, Balamurugan A, McGinnis MD et al. Distinctive KIR and HLA diversity in a panel of north Indian Hindus. Immunogenetics 2002; 53: 1009-1019.

70 Santin I, de Nanclares GP, Calvo B, Gaafar A, Castano L, Bilbao JR. Killer cell immunoglobulin-like receptor (KIR) genes in the Basque population: association study of KIR gene contents with type 1 diabetes mellitus. Hum Immunol 2006; 67: 118-124.

71 Whang DH, Park H, Yoon JA, Park MH. Haplotype analysis of killer cell immunoglobulin-like receptor genes in 77 Korean families. Hum Immunol 2005; 66: 146-154.

72 Middleton D, Menchaca L, Rood H, Komerofsky R. New allele frequency database: http://www.allelefrequencies.net Tissue Antigens 2003; 61: 403-407.

73 Bendukidze N, Ivaskova E. Georgians from Tbilisi, Republic of Georgia. Anthropology/human genetic diversity population reports, vol. 1 IHWG Press: Seattle, WA, 2007.

74 Buhler S, Megarbane A, Lefranc G, Tiercy JM, Sanchez-Mazas A. HLA-C molecular characterization of a Lebanese population and genetic structure of 39 populations from Europe to India-Pakistan. Tissue Antigens 2006; 68: 44-57.

75 Bunce M, Barnardo MC, Procter J, Marsh SG, Vilches C, Welsh KI. High resolution HLA-C typing by PCR-SSP: identification of allelic frequencies and linkage disequilibria in 604 unrelated random UK Caucasoids and a comparison with serology. Tissue Antigens 1997; 50: 100-111.

76 Comas D, Mateu E, Calafell F, Perez-Lezaun A, Bosch E, Martinez-Arias R et al. HLA class I and class II DNA typing and the origin of Basques. Tissue Antigens 1998; 51: 30-40.

77 Dubois V, Gebuhrer L. HLA-A, -B, Cw, -DPB1, -DQB1 and -DRB1 alleles and KIR gene frequencies in a population from south east France. Hum Immunol 2004; 65: 937-939.

78 Evseeva I, Spurkland A, Thorsby E, Smerdel A, Tranebjaerg L, Boldyreva M et al. HLA profile of three ethnic groups living in the north-western region of Russia. Tissue Antigens 2002; 59: 38-43.

79 Ferencik S, Gross-Wilde H. HLA-A, -B, Cw, -DPB1, -DQA1, -DQB1 and -DRB1 allele frequencies in a population from Essen, Germany. Hum Immunol 2004; 65: 945-947. 
80 Ferrara GB, Delfino L, Longo A, Parodi AM. HLA-A, -B, Cw, -DPB1, DQA1, -DQB1 and -DRB1 allele frequencies in a population from Bergamo, Italy. Hum Immunol 2004; 65: 974-980.

81 Grimaldi MC, Crouau-Roy B, Amoros JP, Cambon-Thomsen A, Carcassi C, Orru S et al. West Mediterranean islands (Corsica, Balearic islands, Sardinia) and the Basque population: contribution of HLA class I molecular markers to their evolutionary history. Tissue Antigens 2001; 58: 281-292.

82 Ivanova M, Spassova P, Michailova A, Naumova E. Distributions of HLA class I alleles and haplotypes in Bulgarianscontribution to understanding the origin of the population. Tissue Antigens 2001; 57: 208-215.

83 Lokki ML, Honkavaara E. Finnish from Finland. Anthropology/ human genetic diversity population reports, vol. 1. IHWG Press: Seattle, WA, 2007.

84 Meyer D, Singe RM, Mack SJ, Lancaster A, Nelson MP, Erlich $\mathrm{H}$ et al. Single Locus Polymorphism of Classical HLA Genes, vol. 1. IHWG Press: Seattle, WA, 2007.

85 Nowak J, Mika-Witkowska R, Polak M, Zajko M, RogatkoKoros M, Graczyk-Pol E et al. Allele and extended haplotype polymorphism of HLA-A, -C, -B, -DRB1 and -DQB1 loci in Polish population and genetic affinities to other populations. Tissue Antigens 2008; 71: 193-205.

86 Sanchez-Mazas A, Steiner QG, Grundschober C, Tiercy JM. The molecular determination of HLA-Cw alleles in the Mandenka (West Africa) reveals a close genetic relationship between Africans and Europeans. Tissue Antigens 2000; 56: 303-312.

87 Saruhan-Direskeneli C, Ugar FA. HLA-A, -B, Cw, DQA1, -DQB1 and -DRB1 allele frequencies in a population from Turkey. Hum Immunol 2004; 65: 1183-1185.

88 Tonks S, Bodmer JG, Bodmer W. HLA-A, -B, Cw, DQA1 and -DRB1 allele frequencies in a population from Orkney, Scotland. Hum Immunol 2004; 65: 1069-1071.

89 van der Vlies SA, Voorter CE, van den Berg-Loonen EM. A reliable and efficient high resolution typing method for HLA-C using sequence-based typing. Tissue Antigens 1998; 52: $558-568$.

90 Ferrara GB, Delfino L, Longo A, Morabito A, Parodi AM. HLA-A, -B, Cw, -DPB1, -DQA1, -DQB1 and -DRB1 allele frequencies in a population from North Italy. Hum Immunol 2004; 65: 982-987.
91 Cecuk E, Grubic Z, Stingl K, Zunec R, Brkljacic-Kerhin V. HLA-A and -B allele frequencies in a population from Croatia. Hum Immunol 2004; 65: 912-916.

92 Crespi C, Mila J, Martinez-Pomar N, Etxagibel A, Munoz-Saa I, Priego D et al. HLA polymorphism in a Majorcan population of Jewish descent: comparison with Majorca, Minorca, Ibiza (Balearic Islands) and other Jewish communities. Tissue Antigens 2002; 60: 282-291.

93 Darke C, Guttridge MG, Thompson J, McNamara S, Street J, Thomas M. HLA class I (A, B) and II (DR, DQ) gene and haplotype frequencies in blood donors from Wales. Exp Clin Immunogenet 1998; 15: 69-83.

94 Dunne C, Crowley J, Hagan R, Rooney G, Lawlor E. HLA-A, $\mathrm{B}, \mathrm{Cw}, \mathrm{DRB1}, \mathrm{DQB1}$ and DPB1 alleles and haplotypes in the genetically homogenous Irish population. Int J Immunogenet 2008; 35: 295-302.

95 Gazit E, Kalt R, Loewenthal R. Ashkenazi and non-Ashkenazi Jews from Israel. Anthropology/human genetic diversity population reports, vol. 1. IHWG Press: Seattle, WA, 2007.

96 Grunewald J, Eklund A, Olerup O. Human leukocyte antigen class I alleles and the disease course in sarcoidosis patients. Am J Respir Crit Care Med 2004; 169: 696-702.

97 Ivanova M, Rozemuller E, Tyufekchiev N, Michailova A, Tilanus M, Naumova E. HLA polymorphism in Bulgarians defined by high-resolution typing methods in comparison with other populations. Tissue Antigens 2002; 60: 496-504.

98 Maat W, Haasnoot GW, Claas FH, Schalij-Delfos NE, Schreuder GM, Jager MJ. HLA Class I and II genotype in uveal melanoma: relation to occurrence and prognosis. Invest Ophthalmol Vis Sci 2006; 47: 3-6.

99 Muro M, Marin L, Torio A, Moya-Quiles MR, Minguela A, Rosique-Roman J et al. HLA polymorphism in the Murcia population (Spain): in the cradle of the archaeologic Iberians. Hum Immunol 2001; 62: 910-921.

100 Spinola H, Brehm A, Williams F, Jesus J, Middleton D. Distribution of HLA alleles in Portugal and Cabo Verde. Relationships with the slave trade route. Ann Hum Genet 2002; 66(Pt 4): 285-296.

101 Zahlavova L, Bendukidze N, Ivaskova E. HLA-A, -B, -Cw, -DPB1, -DQA1, -DQB1 and DRB1 allele frequencies in a population from the Czech Republic. Hum Immunol 2004; 65: 925-930.

Supplementary Information accompanies the paper on Genes and Immunity website (http://www.nature.com/gene) 